Jusmal lemiah
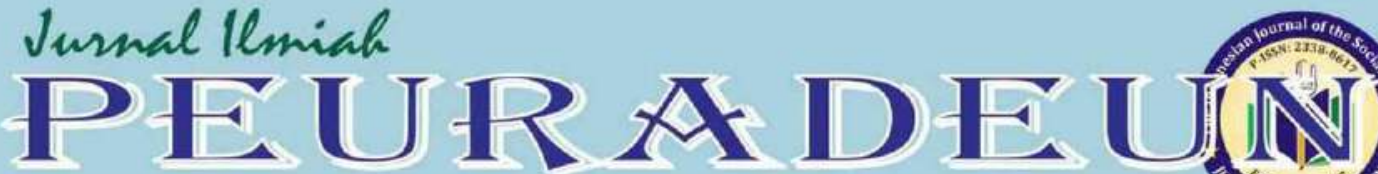

Vol. 8, No. 3, September 2020

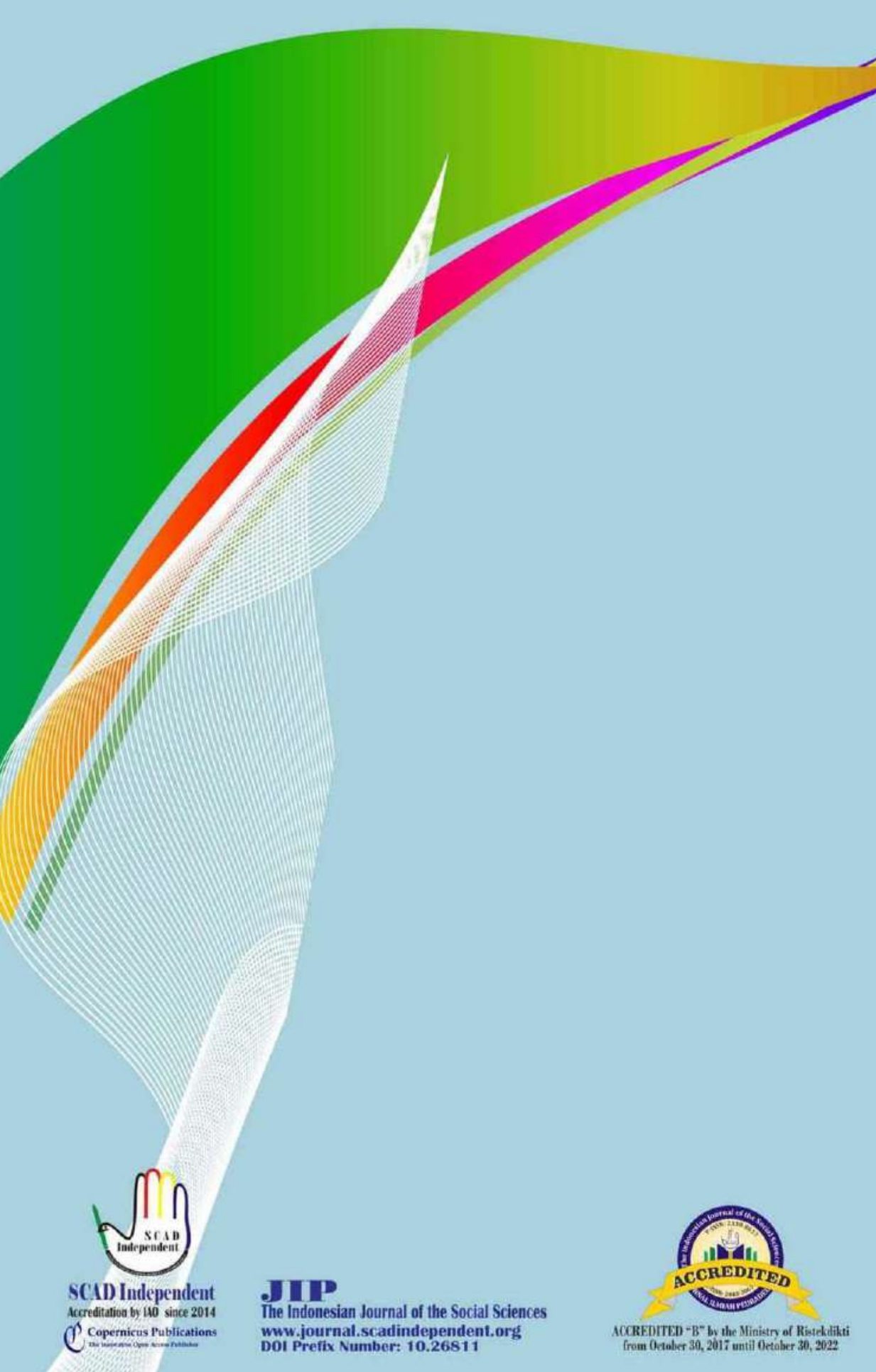

\section{Clarivate Analytics}

Emerging Sources Citation Index Web of Science ${ }^{\mathrm{TM}}$

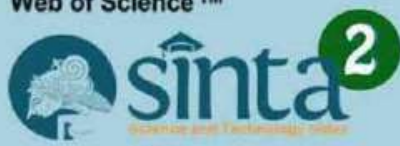

INDEX $\circledast$ COPERNICUS www.journal.scadindependent.org Dot Prefix Number: 10.2681 


\author{
JURNAL ILMIAH PEURADEUN \\ The Indanesian Journal of the Sacial Sciences \\ p-ISSN: 2338-8617/ e-ISSN: 2443-2067
}

www.journal.scadindependent.org

\author{
Vol. 8, No. 3, September 2020
}

Pages: 475-496

\title{
Learning for Children with Special Needs of Dyscalculia
}

\author{
Budi Azhari'; Muhammad Yacoeb ${ }^{2}$; Ade Irfan ${ }^{3}$ \\ 1,2Universitas Islam Negeri Ar-Raniry, Indonesia \\ 3 Universitas Abulyatama, Indonesia
}

\begin{abstract}
Article in Jurnal Ilmiah Peuradeun
Available at : https://journal.scadindependent.org/index.php/jipeuradeun/article/view/550

DOI $\quad$ : http://dx.doi.org/10.26811/peuradeun.v8i3.550
\end{abstract}

\begin{abstract}
How to Cite this Article
APA : Azhari, B., Yacoeb, M., \& Irfan, A. (2020). Learning for Children with Special Needs of Dyscalculia. Jurnal Ilmiah Peuradeun, 8(3), 475-496. doi:10.26811/peuradeun.v8i3.550
\end{abstract}

Others Visit : https://journal.scadindependent.org/index.php/jipeuradeun

Jurnal Ilmiah Peuradeun (JIP), the Indonesian Journal of the Social Sciences, is a leading peer-reviewed and openaccess journal, which publishes scholarly work, and specializes in the Social Sciences that emphasize contemporary Asian issues with an interdisciplinary and multidisciplinary approach. JIP is published by SCAD Independent and published 3 times of year (January, May, and September) with p-ISSN: 2338-8617 and e-ISSN: 2443-2067. Jurnal Ilmiah Peuradeun has become a CrossRef Member. Therefore, all articles published will have a unique DOI number. JIP has been accredited by the Ministry of Research Technology and Higher Education Republic of Indonesia (SK Dirjen PRP RistekDikti No. 48a/KPT/2017). This accreditation is valid from October 30, 2017 until October 30, 2022.

JIP published by SCAD Independent. All articles published in this journal are protected by copyright, licensed under a CC-BY-SA or an equivalent license as the optimal license for the publication, distribution, use, and reuse of scholarly works. Any views expressed in this publication are the views of the authors and not of the Editorial Board of JIP or SCAD Independent. JIP or SCAD Independent cannot be held responsible for views, opinions and written statements of authors or researchers published in this journal. The publisher shall not be liable for any loss, actions, claims, proceedings, demand, or costs or damages whatsoever or howsoever caused arising directly or indirectly in connection with or arising out of the use of the research material. Authors alone are responsible for the contents of their articles.

JIP indexed/included in Web of Science, MAS, Index Copernicus International, Sinta, Garuda, Moraref, Scilit, Sherpa/Romeo, Google Scholar, OAJI, PKP, Index, Crossref, BASE, ROAD, GIF, Advanced Science Index, JournalTOCs, ISI, SIS, ESJI, SSRN, ResearchGate, Mendeley and others. 


\title{
LEARNING FOR CHILDREN WITH SPECIAL NEEDS OF DYSCALCULIA
}

\author{
Budi Azhari'; Muhammad Yacoeb2 ${ }^{2}$ Ade Irfan ${ }^{3}$ \\ 1,2Universitas Islam Negeri Ar-Raniry, Indonesia \\ ${ }^{3}$ Universitas Abulyatama, Indonesia \\ ${ }^{1}$ Contributor Email: budiazhari@ar-raniry.ac.id
}

Received: Juni 12, 2020

Accepted: Aug 27, 2020

Published: Sep 30, 2020

Article Url: https://journal.scadindependent.org/index.php/jipeuradeun/article/view/550

\begin{abstract}
This study aimed to develop mathematics learning tools to help children with special needs of dyscalculia in elementary school. The procedural development of the device was through a 4-D model consisting of four phases; defining, designing, developing, and disseminating. However, based on the research objectives, this development was limited only to the development stage (develop), which is to the learning device testing activities. So the development of learning tools in this study consisted of three main stages, namely: defining, designing, and development. The results of this study illustrated that learning devices for children with dyscalculia learning disorders could help children more easily deal with learning difficulties. Specifically, it is on the topic of sequencing numbers, addition, and subtraction of integers.
\end{abstract}

Keywords:Dyscalculia, Learning Disorder, Learning Device, Children 


\section{A. Introduction}

At the level of basic education, many children experience learning disorders (Shin \& Bryant, 2013), one of the learning disorders that is often found in schools is dyscalculia (Williams, 2013; Arisandi, 2014; Raharjo et al, 2011; Rapin, 2016). The problem of learning disorder occurs almost evenly throughout the world; including developed countries are also inseparable from this problem (Bynner \& Parsons, 1997; Shalev, 2000). The problem at the moment is that dyscalculia is not widely recognized by teachers or education authorities. Many teachers specifically do not understand dyscalculia. So this is the basis for increasing the attention of all parties for children with learning disabilities dyscalculia (Gillum, 2012; Butterworth, Varma, \& Laurillard, 2011).

In Indonesia, it has already begun to show good commitment related to the problem of this learning disorder. This is proven by the existence of regulations and policies to deal seriously with the problem of learning disruptions for students in schools. However, government policies in dealing with student learning disorders in schools do not necessarily work as expected. This is because not all teachers in schools understand the problems of student learning disorders. Though three learning disorders are often found, among these learning disorders are learning disabilities in mathematics (dyscalculia), reading disabilities (dyslexia), and the development of writing disabilities (dysgraphia) (Santrock, 2007). Besides, students who experience learning disabilities also have an impact on the difficulty of students interacting with family and the environment. Furthermore, dyscalculia learning disorders can be caused by two factors, namely primary factors and secondary factors. The primary factor itself is based on disorders of the student's brain (nerves). Meanwhile, secondary disturbances are based on external disturbances and learning patterns (Butterworth et al., 2011).

Several studies have been conducted by experts like Cohen, Lammertyn, and Izard (2008), and Mussolin, De Volder et al (2010) to uncover the influence of primary factors in developmental dyscalculia (Cohen et al., 2008). Although until now there has been no convincing research that this primary factor is the cause of this developmental dyscalculia (Price \& Ansari, 2013). 
Its relationship with external factors, one of which is the weak way of teaching teachers, based on research by Madechan \& Brillante that dyscalculia children have difficulty in learning to count, one of which is caused by learning activities that do not arouse motivation and do not attract students' attention (Madechan \& Brillante, 2008). The consequence of dyscalculia is a representation of the weak use of students' problem-solving strategies that can be said to be immature or inefficient, so students with dyscalculia do not learn the arithmetic facts given, and hence cannot recall them smoothly from their memories. So there is a need for serious handling from teachers and sustainable handling. Students who suffer from developmental disorders learning dyscalculia need guidance and assistance to improve their ability to process arithmetic information, so as not to interfere and damage the acquisition of students' arithmetic skills when attending mathematics learning in school.

Teachers need to know what dyscalculia is so that they can help students in the difficulties they are experiencing. Besides, teachers also need to know the causes and effective strategies in dealing with a child who has dyscalculia (Williams, 2012). However, education is far more complicated, and getting 'results' is not straight forward, due to interference from many variables in the learning environment (Butterworth \& Laurillard, 2010). For that, as instructors and educators, we must know how to provide the right services for them, one of which is an approach or learning strategy that can arouse learning motivation in children with dyscalculia. The low mathematical ability of students with dyscalculia is also inseparable from various factors, from the weaknesses of teaching teachers, low socioeconomic status, to the problem of attention to student behavior that is less than optimal.

In handling dyscalculia learning disorder problems at school, teachers must have special abilities in handling cases of students with dyscalculia learning disorders. But in reality in schools, many teachers do not have a good understanding and sufficient knowledge to help students get out of this dyscalculia learning disorder problem. Even teachers also use the same learning tools as they for normal students in teaching dyscalculia students. 
The focus of the research in this study is to help students learn mathematics with dyscalculia learning disorders. So, researchers are trying to develop instructional materials to help children with dyscalculia learning disorders. Based on preliminary research conducted in 2016 by researchers, it was found that some elementary school students or madrasah ibtidaiyah in Aceh Tamiang experienced dyscalculia learning disorders (Azhari, 2016). So there needs to be an effort in helping students with dyscalculia learning disorders with special learning and special learning devices for students to get out of dyscalculia learning disorder problems.

\section{B. Method}

To find participants with dyscalculia, I began by selecting the children having Mathematics Learning Disorders (MLD) within a cohort of 162 female students and 78 male students. Age 6 years as many as 40 students, age 7 years as many as 93 students, and age 8 years as many as 102 students. Of the 240 students who were given tests based on the results of the analysis and checking the validity of the data carried out repeatedly, it was found that 24 students experienced dyscalculia. Of the 24 students experiencing dyscalculia, the dominant problems found were in sorting the numbers of 18 students, adding eight operations, and having problems in reducing 12 students.

This study uses a qualitative approach, following the research objectives. So, this type of research is a research development, and what will be developed in this research is a learning tool for children with special needs of dyscalculia. The learning device development model used is by modifying the 4-D model from Thiagarajan, Semmel, and Semmel (1974: 5-9). Because it is based on research objectives and various limitations, this development is limited only to the stage of development, which is up to the learning device testing activities. The development of instructional materials in this study consists of three main stages, namely: defining, designing, and developing. 
The validation of the learning device text and research instruments includes the truth of the substance, conformity to the level of student thinking, and conformity to the main principles, characteristics, and steps of learning. The truth of the substance and suitability of students' level of thinking refers to the indicators proposed by O'Meara, which include indicators: (1) format, (2) language, (3) illustration and (4) content adjusted to the cognitive level of students who have previously mapped (Usman, 2009).

Based on the evaluations, corrections, input and suggestions of the validators, a revision of the learning tool and research instrument of the draft I is then carried out, so that the tools and instrument II of the draft are obtained, this is also repeated until draft III, and if necessary until draft IV as the end of development of devices to help students with dyscalculia learning disorders. After the draft development of the device can be used, the researcher applies the learning device to the other dyscalculia students or to the dyscalculia students who are not involved in the development of the learning device development test.

\section{Results and Discussion}

\section{Results}

The development phase starts from the development of the learning device which starts from the draft I, then is validated and tested on the device. Validation of experts is intended to determine the validity of the content (content validity). The validation results of the experts were used as a basis for revising and refining the draft I learning kit. Improved learning tools based on input from the validators were tested on students who were previously identified as having dyscalculia. This flow continues until the IV draft or learning device is believed to be able to assist students in overcoming dyscalculia learning disorders as the aim of this study.

\section{a. Expert Validation}

After the researchers compiled the first draft of the learning kit, experts validated it, this involved mathematicians, mathematics learning 
experts, psychology experts and children, and grade II SD / MI teachers. The revised learning tool is based on the input from these validators before being trialed. Based on the input from the validator, several revisions were made to produce learning tools in draft II. Some important notes considered for revision are as follows:

Table 1. Revised dyscalculia test

\begin{tabular}{|c|c|}
\hline being revised & After being revised \\
\hline $\begin{array}{l}\text { n number } 1 \text { contains } 4 \text { items of } \\
\text { ation numbers }\end{array}$ & $\begin{array}{l}\mathrm{n} \text { number } 1 \text { contains } 2 \text { items } \\
\text { fication numbers }\end{array}$ \\
\hline $\begin{array}{l}\text { Question number } 3 \text { counts down from } \\
20 \text { to } 0 \text { and continues to } 50\end{array}$ & 3 count down from \\
\hline $\begin{array}{l}\text { Question number } 5 \text { continues the } \\
\text { shape of the image }\end{array}$ & Deleted \\
\hline $\begin{array}{l}\text { Question numbers } 6 \text { and } 7 \text { sign the } \\
\text { operation on the left }\end{array}$ & $\begin{array}{l}\text { Question number } 6 \text { and } 7 \text { sign } \\
\text { operation on the right }\end{array}$ \\
\hline & $\begin{array}{l}\text { Deleted (not suitable with students } \\
\text { cognitive) }\end{array}$ \\
\hline $\begin{array}{l}\text { number } 9 \text { is the meaning of } \\
\text { on }\end{array}$ & $\begin{array}{l}\text { Deleted (not suitable with students } \\
\text { cognitive) }\end{array}$ \\
\hline number 17is about addition 3 & ed (already exist) \\
\hline $\begin{array}{l}\text { Question number } 21 \text { is about rewriting } \\
\text { the number }\end{array}$ & Deleted (alre \\
\hline $\begin{array}{l}\text { Question number } 22 \text { writing the two- } \\
\text { dimensional figure }\end{array}$ & $\begin{array}{l}\text { d (not suitable with students } \\
\text { (ve) }\end{array}$ \\
\hline $\begin{array}{l}\text { Question number } 23 \text { adding in the } \\
\text { form of similarity }\end{array}$ & $\begin{array}{l}\text { Deleted (not suitable with students } \\
\text { cognitive) }\end{array}$ \\
\hline The total of the que & questions is 17 \\
\hline
\end{tabular}

Table 2. Revised Learning scenario

\begin{tabular}{|l|l|}
\hline \multicolumn{1}{|c|}{ Before being revised } & \multicolumn{1}{c|}{ After being revised } \\
\hline $\begin{array}{l}\text { The learning scenario does not use the } \\
\text { step of learning in detail. }\end{array}$ & $\begin{array}{l}\text { The learning scenario is made with a } \\
\text { detailed step. } \\
\text { The use of the media in learning is not } \\
\text { appropriate because there are no stages. } \\
\text { The students learn individually which is of media is adjusted with the } \\
\text { learning stages. }\end{array}$ \\
$\begin{array}{l}\text { not good for students' comprehension. } \\
\text { There is no conclusion at the end of the } \\
\text { learning to provide a good summary of the } \\
\text { material. }\end{array}$ & $\begin{array}{l}\text { the students can learn in a group. } \\
\text { conclusion to emphasizea good summary. }\end{array}$ \\
\hline
\end{tabular}


Budi Azhari et al.

Tabel 3. Revised LKPD

\begin{tabular}{|l|l|}
\hline \multicolumn{1}{|c|}{ Before being revised } & \multicolumn{1}{c|}{ After being revised } \\
\hline $\begin{array}{l}\text { The background image shifts the focus } \\
\text { of the students }\end{array}$ & $\begin{array}{l}\text { The background image is fixed with } \\
\text { a proper size. } \\
\text { The color does not attract students' } \\
\text { interest }\end{array}$ \\
$\begin{array}{l}\text { The folor is changed and adjusted to } \\
\text { catch students' interest. }\end{array}$ \\
$\begin{array}{l}\text { The space to write provided is narrow } \\
\text { The steps in doing the task should be } \\
\text { provided in LKPD for the students }\end{array}$ & $\begin{array}{l}\text { The font the letter is fixed to } \\
\text { adjust the student's sight } \\
\text { The steps in doing the task are } \\
\text { added }\end{array}$ \\
\hline
\end{tabular}

\section{b. Testing}

Trials are conducted to see the suitability of the time required while introducing the teacher about learning tools developed for dyscalculia students. Based on the results of the trials, re-improvements were made to the learning tools and instruments that were developed. In the Student Worksheet (LKPD) improvements are made to the tasks that students are doing, and the learning scenario is done to improve the suitability between the uses of the scenario with the media used. In the learning achievement test, there was a revision of the question in which the language used was not by students' cognitive and it was not easy for students to understand.

Trials at this stage of development are trials of learning tools conducted by researchers with observers from the research team with grade II elementary school teachers. The learning tools tested were dyscalculia test, learning scenario, student worksheet, and student achievement test. The learning scenario trial also aims to find out the clarity and readability as well as to see the suitability and suitability of the strategies, methods, and media used. While the dyscalculia test instrument testing is intended to obtain a clear picture of whether this instrument can reveal and identify students who have learning disabilities dyscalculia or students who only have learning difficulties.

The results of the trial will be used to revise and refine the learning tools and research instruments to produce a draft III learning device. The trial data is presented in the following table: 
Table 4 Revised Dyscalculia test

\begin{tabular}{|l|l|}
\hline \multicolumn{1}{|c|}{ Before testing } & \multicolumn{1}{|c|}{ After being revised } \\
\hline $\begin{array}{l}\text { Question number } 17 \text { every image } \\
\text { represents the symbol of operation } \\
\text { and number }\end{array}$ & $\begin{array}{l}\text { Question number } 17 \text { each image } \\
\text { represents the symbol of the only } \\
\text { The total of Question is } 24\end{array}$ \\
The total of the question is 17 \\
\hline
\end{tabular}

Table 5. Revised Learning Scenario

\begin{tabular}{|l|l|}
\hline \multicolumn{1}{|c|}{ Before being Revised } & \multicolumn{1}{|c|}{ After being Revised } \\
\hline $\begin{array}{l}\text { Learning about knowing the } \\
\text { numbers with apple card still does } \\
\text { not meet the goal. }\end{array}$ & $\begin{array}{l}\text { The learning of knowing numbers is } \\
\text { done not only with the medium of } \\
\text { apple card but with the numbered } \\
\text { card. }\end{array}$ \\
\hline
\end{tabular}

\section{c. Data Analysis of Test Results}

Data analysis of the testing results is intended to describe the process of implementing teaching and learning activities during the trial which includes tests of learning outcomes and student activities during the learning process. The data analyzed are as follows.

1) Learning Outcomes Test

a) Validity

Based on the product-moment correlation formula, the validity of each test item is obtained as follows:

Table 6.The validity of the test item

\begin{tabular}{|c|c|c|c|c|}
\hline Number of question & $\mathbf{1}$ & $\mathbf{2}$ & $\mathbf{3}$ & $\mathbf{4}$ \\
\hline $\mathrm{r}_{\mathrm{xy}}$ & 0,44 & 0,75 & 0,43 & 0,80 \\
\hline Level of Validity & Sufficient & High & Sufficient & Very high \\
\hline
\end{tabular}

Based on the data in the above table, in general, the validity of each test item is considered suitable for use without revision. 


\section{b) Sensitivity}

Based on the sensitivity calculation, it is obtained that the sensitivity of each test item is as follows:

Table 7. The sensitivity of Test item

\begin{tabular}{|c|c|c|c|c|}
\hline Number of Question & $\mathbf{1}$ & $\mathbf{2}$ & $\mathbf{3}$ & $\mathbf{4}$ \\
\hline Sensitivity & 0,46 & 0,64 & 0,84 & 0,76 \\
\hline
\end{tabular}

Based on the above table, it can be seen that each test item is sensitive to learning, thus each test item is considered suitable for use without revision.

\section{c) Reliability}

Based on the calculation of test reliability, the test reliability coefficient $\alpha=0.72$ was obtained. This means that learning outcomes tests have high reliability. Thus the learning outcomes test can be used to measure students' abilities.

\section{2) Student Activities during Learning}

The results of observations of student activities in learning each meeting four times face to face expressed as a percentage. These results are summarized in Table 8.

Tabel 8. Percentage of Students Activities

\begin{tabular}{|c|c|c|c|c|c|}
\hline \multirow[b]{2}{*}{ Observation Category } & \multicolumn{4}{|c|}{ Percentage of Students Activities } & \multirow{2}{*}{$\begin{array}{c}\text { Effectivenes } \\
\text { s Tolerance } \\
(\%)\end{array}$} \\
\hline & $\begin{array}{c}\text { SP } \\
\text { I }\end{array}$ & $\begin{array}{c}\text { SP } \\
\text { II }\end{array}$ & SP III & $\begin{array}{l}\text { SP } \\
\text { IV }\end{array}$ & \\
\hline $\begin{array}{l}\text { a. Listening/paying } \\
\text { attention to the } \\
\text { teacher explanation }\end{array}$ & 8,33 & 14,63 & 12,22 & 14,81 & $5-15$ \\
\hline $\begin{array}{l}\text { b. Reading/ } \\
\text { understanding the } \\
\text { problem }\end{array}$ & 24,81 & 13,7 & 11,3 & 16,67 & $10-20$ \\
\hline $\begin{array}{l}\text { c. Solving the problem/ } \\
\text { finding the answer }\end{array}$ & 29,44 & 27,04 & 30,37 & 24,44 & $25-35$ \\
\hline
\end{tabular}




\begin{tabular}{|l|c|c|c|c|c|}
\hline \multirow{2}{*}{ Observation Category } & \multicolumn{3}{|c|}{ Percentage of Students Activities } & Effectivenes \\
\cline { 2 - 5 } & $\begin{array}{c}\text { SP } \\
\text { I }\end{array}$ & $\begin{array}{c}\text { SP } \\
\text { II }\end{array}$ & SP III & $\begin{array}{c}\text { SP } \\
\text { IV }\end{array}$ & $\begin{array}{c}\text { Solerance } \\
\text { (\%) }\end{array}$ \\
\hline $\begin{array}{l}\text { and the way to solve } \\
\text { the problem }\end{array}$ & & & & & \\
\hline $\begin{array}{l}\text { d. Having Discussion/ } \\
\text { Asking the } \\
\text { students/teacher }\end{array}$ & 13,7 & 23,52 & 10,57 & 14,26 & $10-20$ \\
\hline $\begin{array}{l}\text { e. Doing the students } \\
\text { worksheet }\end{array}$ & 6,29 & 6,85 & 8,33 & 10,34 & $5-15$ \\
\hline $\begin{array}{l}\text { f. Observing the result } \\
\text { of the work }\end{array}$ & 10,37 & 5,37 & 16,67 & 10,37 & $5-15$ \\
\hline $\begin{array}{l}\text { g. Concluding } \\
\text { procedure or concept }\end{array}$ & 6,48 & 8,52 & 10,19 & 6,67 & $5-15$ \\
\hline $\begin{array}{l}\text { h. Irrelevant attitude in } \\
\text { learning }\end{array}$ & 0,37 & 0,37 & 0,56 & 2,04 & $0-5$ \\
\hline \begin{tabular}{l} 
Total (\%) \\
\hline
\end{tabular} & $\mathbf{1 0 0}$ & $\mathbf{1 0 0}$ & $\mathbf{1 0 0}$ & $\mathbf{1 0 0}$ & \\
\hline
\end{tabular}

Based on the table above for SP I, the second observation category is ineffective because it exceeds the tolerance of effectiveness and the other seven categories are classified as effective. For SP II, the fourth observation category was ineffective because it exceeded effectiveness tolerance and the other seven categories were classified as effective. For SP III, the sixth observation category is ineffective because it exceeds effectiveness tolerance and the other seven categories are classified as effective. For SP IV, the third observation category is almost under the tolerance of effectiveness but this is considered effective and the other seven categories are in the tolerance of effectiveness. Thus the activities of students in each SP can be said to be effective.

After conducting a series of validations and trials of the learning device in draft III, and it is believed that this draft can already be used, the next, the researcher conducts the final test or the application of learning using the learning device that has been tested and validated, to students who are the subjects of this study namely students with dyscalculic learning disorders. The application of learning from developed devices includes the problem of ranking numbers, addition operations, and subtraction operations. 


\section{3) Description of the Use of Learning Devices}

In the following explanation, it illustrates some cases experienced by students in the study program to give an overview of the problems they face, then the application/treatment is presented as a form of application of the learning device that has been tested.

a) The Problems of Sorting Numbers

Based on the results of the study, it is noted that there are 18 students with dyscalculia who have problems sorting numbers. Students have difficulty placing the numbers in order. Errors occur when the dyscalculia students sort the numbers from the largest to the smallest. As done by the SS in this study.

Table 9. Testing the use of learning devices to sort numbers

The case of SS can write the numbers $0,1,2,3,4,5,6,7,8,9,10$ easily but when the students are asked the sort of numbers from the biggest number to the smallest number, the SS make a mistake by writing 4 at the fourth position. It showed that the SS tends to memorize the number position by not knowing the meaning of the sorting number.

\begin{tabular}{|l|l|} 
Isila h titik-titik berikut dengan bilangan yang sesuai \\
$1,2, \ldots, 4,5,6,7,8,9,10$ \\
$5,4,3, \ldots, 5$.
\end{tabular}




\begin{tabular}{|l|l|}
\hline $\begin{array}{l}\text { sequencing the number dan the way to sort the number, at this } \\
\text { stage the students are tested with the abstract concept of sorting } \\
\text { numbers. The students were given the numbered card and then the } \\
\text { researcher asked the dyscalculia students to sequence the numbered } \\
\text { card from the smallest number to the biggest number. The process } \\
\text { of giving the numbered card to make sure that the dyscalculia } \\
\text { students had understood the sequence number and can sort the } \\
\text { number is appropriate with the instruction given. }\end{array}$ \\
\hline
\end{tabular}

\section{b) The problem besides}

Based on the results of the study, it is noted that there are 8 students with dyscalculic problems besides. Mistakes made by students besides begin with the inability of students to understand the concepts and sequences of numbers.

\section{Table 10. Testing the use of summation learning tool}

The case of the student TT who made a mistake in determining the result of summation, for example, $12+3=16$. This mistake occurred because the students were wrong in counting the result of summation. The students often made mistakes in predicting incorrect numbers so that they took the wrong conclusion. For instance the case in this research, the students assumed that the first number is 13 so the students conclude that the result is 16

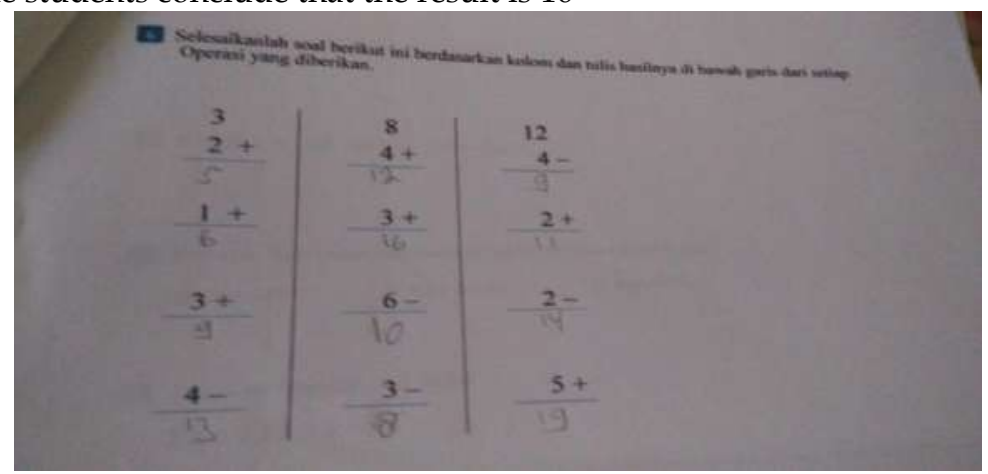

Another mistake is when the students count the summation by using fingers. When using fingers, TT was often wrong in starting the summation given. For example, in this research when the students were asked to add 17 and 5. TT counted with the fingers and it started from 17 and then 18, 19, 20, 21. Therefore, the result obtained is 21 .

\begin{tabular}{|l|l|}
\hline Stage I & $\begin{array}{l}\text { The student was given Cuisenaire rod gradually as many as ten } \\
\text { rods. It was started by giving five rods at the beginning and } 5 \text { rods } \\
\text { at the end to the student who suffers dyscalculia and then they were } \\
\text { asked to use the rods and sum them. The researcher gave one rod } \\
\text { of Cuisenaire in this it was a chocolate rod and asked the }\end{array}$ \\
\hline
\end{tabular}




\begin{tabular}{|c|c|}
\hline & $\begin{array}{l}\text { Dyscalculia students to arrange two other rods that have a similar } \\
\text { length with the chocolate rods. The students took the purple rod } \\
\text { and yellow rod. In the beginning, the student arranged the rods } \\
\text { sideways. The researcher then asked the dyscalculia student to see } \\
\text { the rod Cuisenaire which had been arranged whether if the rods } \\
\text { were arranged in that way could reach the height as a chocolate rod } \\
\text { or not? The dyscalculia student realized his mistake and fix the } \\
\text { position of the rods. The dyscalculia students then place the second } \\
\text { rod in vertical. However, the result is still wrong in which the } \\
\text { length combination of the rod chosen exceeded the length of the rod } \\
\text { given. }\end{array}$ \\
\hline Stage II & $\begin{array}{l}\text { At this stage, the researcher introduces a number that represents the } \\
\text { color of the Cuisenaire rod. Students are then asked to slowly } \\
\text { remember each number represented by the color. The first step } \\
\text { students are asked to remember the numbers } 1 \text { to } 5 \text { of the colors } \\
\text { represented by the Cuisenaire rod where the white rod represents } \\
\text { number } 1 \text {, the red rod represents number } 2 \text {, the light green rod } \\
\text { represents number } 3 \text {, the purple rod represents number } 4 \text {, the } \\
\text { yellow rod represents number } 5 \text {. To make it easier remember the } \\
\text { researchers then make abbreviations P (1), M (2), HM (3), U (4), and } \\
\mathrm{K}(5) \text {. The researcher then took the yellow rod and asked students to } \\
\text { look for the other two rods which had lengths following the yellow } \\
\text { rods given. Students take the purple rod and the light green rod } \\
\text { puts the two sticks beside the given yellow rod. However, the } \\
\text { length of the two rods selected by the students did not match the } \\
\text { length of the yellow rods given. Students quickly realize that it is } \\
\text { wrong because it is incompatible with the yellow rods given. } \\
\text { Students then re-select the other rods, the white and red rods and } \\
\text { place them side by side with the given yellow rods, but the lengths } \\
\text { of the two rods have not reached the length of the yellow rods. }\end{array}$ \\
\hline Stage III & $\begin{array}{l}\text { Students are then known as dark green rods representing number } 6 \text {, } \\
\text { black rods represent number } 7 \text {, brown rods represent number } 8 \text {, } \\
\text { blue rods represent number 9, and dark orange rods represent } \\
\text { number } 10 \text {. To make it easier for students to be scalable in } \\
\text { remembering the numbers represented by that number then The } \\
\text { researcher makes abbreviations HT (6), H (7), C (8), B (9), and JT } \\
\text { (10). The researcher then gives the dyscalculia students the brown } \\
\text { color and asks students to look for two other rods which, when } \\
\text { combined, will have the same length as the chocolate rod. Students } \\
\text { take the light green rod and place it next to the chocolate rod. Then } \\
\text { take the purple rod and place it on the light green rod. Students } \\
\text { then pay attention to the results turns out then students conclude } \\
\text { that the results are wrong because the length formed by students } \\
\text { from the two rods that are given does not match the length of the } \\
\text { rods given. Students then take the other rod, namely the dark green } \\
\text { rod and the orange rod, and place it next to the chocolate rod which }\end{array}$ \\
\hline
\end{tabular}




\begin{tabular}{|l|l|}
\hline $\begin{array}{l}\text { is given then obtained the same length. Students then know that the } \\
\text { results are correct because of the same length. The researcher then } \\
\text { said that so } 8 \text { was obtained from } 6 \text { (dark green) plus } 2 \text { (orange). The } \\
\text { researchers then took the other two light green and yellow rods and } \\
\text { placed them next to the brown rods. The researcher tells students } \\
\text { that eight can also be obtained from } 5 \text { (yellow) plus } 3 \text { (light green). } \\
\text { Also, researchers said that it could also be said } 3 \text { (light green) plus } 5 \\
\text { (yellow). So students can determine the results of the sum given } \\
\text { well. }\end{array}$ \\
\hline
\end{tabular}

\section{c) Subtraction Problems}

Based on the results of the study it was noted that there are 12 students with dyscalculic problems in subtraction. The errors made by the dyscalculia student in principle are not much different from the difficulty of students besides where there is an inability of students to understand the concepts and sequences of numbers.

\section{Table 11. Testing the use of learning subtraction devices}

In the case of subtraction, in this study, it was found that the difficulties experienced by students of dyscalculia as done by $\mathrm{HH}$, where $\mathrm{HH}$ is not just making a mistake in understanding the concepts of numbers and sequences but also make a mistake by assuming the concept of subtraction are addition. In this study, for example, 9-4 = 13 .

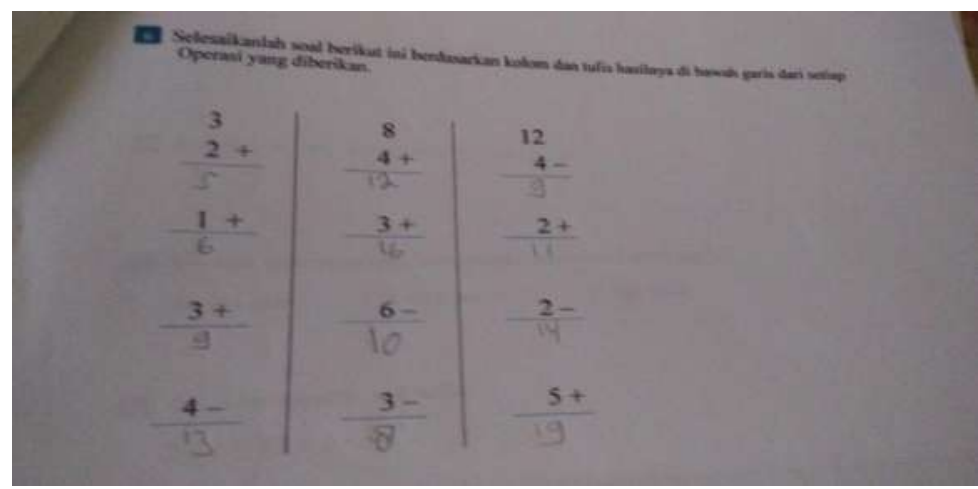

Another mistake made by $\mathrm{HH}$ and students who experienced the same problem in subtraction was an error in making a subtraction using fingers. For example in a study when $\mathrm{HH}$ subtracted 10 and 3 students answered 8 . This is because $\mathrm{HH}$ mistakenly started subtracting using fingers where students assumed that the result was where the fingers stopped namely 10,9 , and 8 . So the result was 8 . 


\begin{abstract}
Trying to improve learning disorders for $\mathrm{HH}$ and other dyscalculia students in the subtraction carried out by providing mathematics learning assistance by using a learning device that has been developed and also using teaching aids namely the Cuisenaire rod as well.
\end{abstract}

\begin{tabular}{|c|c|}
\hline Stage I & $\begin{array}{l}\text { The learning process carried out by students with the number of rods } \\
\text { rejected is requested in the additional activity. The researcher and } \\
\text { dyscalculia student then use the rods in the subtraction Operation. The } \\
\text { researcher gives two pieces of equipment on the blue rod (9) and the } \\
\text { yellow rod (5) students then look for another one that is provided by } \\
\text { the rod above the yellow rod with the blue rod will add the same } \\
\text { length. Students then choose a dark green rod (6) then place it on top of } \\
\text { the yellow rod and obtain a length that is longer than the given blue } \\
\text { rod length. Students then look for another rod, namely the light green } \\
\text { rod (3) then return to the top of the yellow rod and get less than the } \\
\text { given blue rod. Students then look for another rod, the purple one (4), } \\
\text { and place it on a yellow one and get the same length as the given blue } \\
\text { one. The researcher then asked students to draw blue rods and other } \\
\text { rods on paper and asked for the numbers of each rod on the drawing } \\
\text { paper then explained that } 9 \text { (blue) was reduced by } 5 \text { (yellow) to } 4 \\
\text { (purple). The researcher then explained that } 9 \text { (blue) minus } 4 \text { (purple) } \\
\text { were equal to } 5 \text { (yellow). }\end{array}$ \\
\hline Stage II & $\begin{array}{l}\text { The researcher then took another rod, namely, the yellow rod (5) and } \\
\text { the white rod (1) then asked students to look for another rod which } \\
\text { when placed on a white rod and side by side with the yellow rod } \\
\text { would have the same length. The dyscalculia student then took the } \\
\text { light green rod (3) and placed it on the white rod (1) and got an } \\
\text { unequal length result, where the combination of a light green and } \\
\text { white rod placed side by side with the yellow rod was still not long } \\
\text { enough with the given yellow rod. }\end{array}$ \\
\hline Stage III & $\begin{array}{l}\text { Next, the dyscalculia students are asked to take the purple rod (4) } \\
\text { and place it on the white rod (1). The researcher then asks students } \\
\text { to reproduce the correct Cuisenaire rod pattern on the given sheet } \\
\text { and states that } 5 \text { (yellow) minus } 1 \text { (white) is equal to } 4 \text {. The } \\
\text { researcher then reinforces that } 5 \text { minus } 1 \text { is equal to } 4 \text {. The } \\
\text { researcher then confirms that } 5 \text { minus } 4 \text { equals to } 1 \text {. }\end{array}$ \\
\hline
\end{tabular}




\section{Discussion}

Many skills are affected by dyscalculia, such as inhibiting the work of the brain, difficult to socialize, difficult to manage money, time, direction, symbolic, graphic, and more abstract mathematical representations (Beacham \& Trott, 2005; Butterworth et al., 2011). Therefore, in this study, researchers conducted the development of learning devices for children with dyscalculia. There are several reasons which then researchers need to conduct this study in more depth. First; the researcher wants to give or add a reference for researchers or education observers especially those who are interested in the issue of dyscalculia, moreover children with dyscalculia learning disorder have various problem characteristics. So that helping them to learn mathematics needs attention to the problems faced by the students in real. Teachers have the responsibility to help children with learning disabilities by taking a learning approach that supports children to overcome the problem of learning disabilities (Essa \& El-Zeftwy, 2015).

Second, it is necessary to broaden previous findings by showing that the characteristics of the problem are always different even on the same sub-theme. Third, these findings indicate that the learning tools developed need to consider learning classically and individually. This is based on the condition of the school; especially teachers in Indonesia, in general, do not generally understand well the dyscalculia learning disorder (Azhari, 2016). So that it is hoped that with the development of these learning tools, teachers can assist students in learning mathematics for dialysis students both individually and also classically.

The development of this learning tool starts from the development of a device starting from the draft I which covers a set of dyscalculia test questions, a set of learning scenarios, and a Student Worksheet (LKPD). The first draft was developed, then validated and tested the device. Validation of experts is intended to determine the validity of the content (content validity). The results of the experts' validation were used as a basis for revising and refining the draft I learning kit. Furthermore, the learning tools that had been improved based on input from the validators 
were retried on students who were previously identified as having dyscalculia. This flow continues until the IV draft or learning device is believed to be able to assist students in overcoming dyscalculia learning disorders as the aim of this study. Through this LKPD that has been developed and tested, it is hoped that it can help students in facing their learning difficulties.

The trial was conducted to see the suitability of the time needed while introducing the teacher about the learning tools developed for dyscalculia students. Based on the results of the trials, re-improvements were made to the learning tools and instruments that were developed. In the LKPD improvements were made to the tasks undertaken by students, and the learning scenario carried out an improvement in the compatibility between the use of the scenario and the media used. In the learning achievement test, there was a revision of the question in which the language used was not following students' cognitive and it was not easy for students to understand.

After conducting a series of validations and trials of the instructional device, and it is believed that all instruments can be used, the next, the researcher conducts the final test or the application of learning using the instructional device that has been tested and validated, on students who are the subject of this study, students with a dyscalculia learning disorder. The application of learning from developed devices includes the problem of ranking numbers, addition operations, and subtraction operations.

Dyscalculia children find it difficult to see patterns of connectedness in numbers and also patterns of numbers, as described by Emerson \& Babtie (2014) that students of dyscalculia have no understanding of the place value rod where the value of numbers depends on their position in numbers, nor do they understand the principle of exchange that supports values the place. With the learning tools developed in this study with due regard to the characteristics of students with dialysis, it can help students learn mathematics. 
To be able to explain numbers, students must understand how numbers consist of patterns and structures. Students need to spend time becoming familiar with various number patterns and with a base of ten and a place value structure. They need to have an understanding of the principles of abstract mathematics (Kay \& Yeo, 2003). Therefore, the LKPD considers student activities in understanding abstract concepts through learning activities.

Based on the exposure to the results of the study there were 18 students with dyscalculia who had problems in sorting numbers. Students have difficulty placing the numbers in order. Errors occur when the dyscalculia students sort the numbers from the largest to the smallest. As done by the SS in this study. Efforts to assist students in sorting numbers are done by providing mathematics learning assistance using pre-developed learning tools, including using teaching aids namely Cuisenaire rods, apple cards, and number cards. Learning for students who have difficulty in sorting numbers is done by first checking back the mistakes made in sorting numbers than making students understand the concept of numbers. This learning can help students overcome their learning difficulties.

Related to the students' difficulties of addition operations, as experienced by 8 students in this study, the difficulty of students, besides, begins with the inability of students to understand the concepts and sequences of numbers. So that also affects other mathematical operations. One of them is, as done by the TT which is wrong in determining the results of the sum eg. 12 $+3=16$. This error occurs because students are wrong in calculating the results of the sum. Students are often wrong by guessing wrong numbers so they draw wrong conclusions. For example in the case of this study students assumed the first number 13 so that students concluded that the result was 16 .

Efforts to help TT and other dyscalculia students who experience the same problem, besides, are done using the developed learning device and also use teaching aids that are following the considerations that have been tested, namely the Cuisenaire rod. The giving of the Cuisenaire rod is to create flexible learning. Student activities are more dominant in carrying out activities that are relevant to learning because students are more invited to learn in a fun way not only given an understanding through 
abstract symbols. In the learning process using various types of varied games will make children feel happy and not easily bored in learning (Azhari \& Irfan, 2019; Triharso, 2013: 47).

Likewise with the difficulties of students in subtraction operations, in this study, there were 12 students with dyscalculia who experienced difficulties in subtraction. The errors made by the scalable student in principle are not much different from the difficulty of students besides where there is an inability of students to understand the concepts and sequences of numbers. In this study, it can be seen for example $9-4=13$. Accordingly, the effort to help students overcome this problem, by providing mathematics learning assistance by using learning tools that have been developed and tested before, as well as using teaching aids namely Cuisenaire rods as well, as a tool. Thus, learning interventions through the learning tools used can help students overcome their learning difficulties. For dyscalculia's children, interventions (doing something to change a condition) earlier will help children more easily to face difficulties (Fatima, 2018).

\section{Conclusion}

Based on the results of research and development that has been carried out in this study, it can be concluded that this development research generated a product of Mathematics learning tools that can help children with dyscalculia learning disorders. The device development is carried out in several stages, namely: a) defining, b) designing, and c) developing. Each step is adjusted to the material that is the focus of this research, namely the material that is the basis so that children who experience dyscalculia learning disorders in the material sorting numbers, addition, and subtraction of integers in this study can be assisted in overcoming mathematical learning difficulties. Learning tools for children with learning disabilities that have been developed, and have been tested and implemented in this study, have helped children more easily deal with learning difficulties, especially on the topic of sequencing numbers, addition and subtraction of integers. 


\section{Acknowledgment}

We would like to thank all participants involved in this study. We would also like to thank The Center of Research and Community Service, UIN Ar-Raniry. The study was financed by a Research Grant - 2018 from Universitas Islam Negeri Ar-Raniry Banda Aceh.

\section{Bibliography}

Abtahi, M., \& Battell, C. (2017). Integrate Social Justice Into the Mathematics Curriculum in Learning. Jurnal Ilmiah Peuradeun, 5(1), 101-114. doi:10.26811/peuradeun.v5i1.123

Arisandi, E. (2014). Meningkatkan Kemampuan Operasi Perkalian untuk Anak Diskalkulia Melalui Metode Garismatika. Jurnal Penelitian Pendidikan Khusus, 3(3).

Azhari, B. (2017). Identifikasi Gangguan Belajar Dyscalculia Pada Siswa Madrasah Ibtidaiyah. Al Khawarizmi: Jurnal Pendidikan Dan Pembelajaran Matematika, 1(1), 60-74.

Azhari, B., \& Irfan, A. (2019). Model-Eliciting Activities dalam Menganalisis Kreativitas Pemecahan Masalah Matematika Pada Mahasiswa Pendidikan Matematika di PTKIN Aceh. Al Khawarizmi: Jurnal Pendidikan dan Pembelajaran Matematika, 2(1), 1-18.

Beacham, N., \& Trott, C. (2005). Screening for dyscalculia within HE. MSOR Connections, 5(1), 1-4.

Butterworth, B., \& Laurillard, D. (2010). Low numeracy and dyscalculia: identification and intervention. ZDM, 42(6), 527-539.

Butterworth, B., Varma, S., \& Laurillard, D. (2011). Dyscalculia: from brain to education. science, 332(6033), 1049-1053.

Bynner, J. \& Parsons, S. (1997). Does Numeracy Matter? London: The Basic Skills Agency. Institute of Education: London.

Emerson, J., \& Babtie, P. (2014). The dyscalculia assessment. Bloomsbury Publishing.

Essa, H. A. E. G. E., \& El-Zeftawy, A. M. A. (2015). Teachers' knowledge, attitudes, and reported strategies to assess and support students with learning difficulties. Journal of Nursing and Health Science, 4(2), 79-92. 
Fathimah, N. S., \& Ishartiwi, I. (2018). Pengembangan multimedia permainan interaktif pembelajaran berhitung bagi anak diskalkulia usia prasekolah. Jurnal Inovasi Teknologi Pendidikan, 5(2), 115-128.

Fonna, M., \& Mursalin, M. (2018). Role of Self-Efficacy Toward Students' Achievement in Mathematical Multiple Representation Ability (MMRA). Jurnal Ilmiah Peuradeun, 6(1), 31-40. doi:10.26811/peuradeun.v6i1.174

Gillum, J. (2012). Dyscalculia: issues for practice in educational psychology. Educational psychology in practice, 28(3), 287-297.

Gillum, J. (2012). Dyscalculia: issues for practice in educational psychology. Educational psychology in practice, 28(3), 287-297.

Husen, S., \& Mansor, R. (2018). Parents Involvement in Improving Character of Children Through Mathematics Learning. Jurnal Ilmiah Peuradeun, 6(1), 41-50. doi:10.26811/ peuradeun.v6i1.178

Kadosh, R. C., Lammertyn, J., \& Izard, V. (2008). Are numbers special? An overview of chronometric, neuroimaging, developmental, and comparative studies of magnitude representation. Progress in neurobiology, 84(2), 132-147.

Kay, J., \& Yeo, D. (2003). Dyslexia and maths. Routledge.

Madechan, \& Desiana, B.N. (2008). Media Benda Nyata untuk Menyelesaikan Soal Cerita Matematika Siswa Diskalkulia. Jurnal Pendidikan Luar Biasa, 4(1), 38-46.

Mussolin, C., De Volder, A., Grandin, C., Schlögel, X., Nassogne, M. C., \& Noël, M. P. (2010). Neural correlates of symbolic number comparison in developmental dyscalculia. Journal of cognitive neuroscience, 22(5), 860-874.

Patimah, S., \& Tabrani ZA. (2018). Counting Methodology on Educational Return Investment. Advanced Science Letters, 24(10), 7087-7089. https://doi.org/10.1166/asl.2018.12414

Price, G. R., \& Ansari, D. (2013). Dyscalculia: Characteristics, causes, and treatments. Numeracy, 6(1), 1-16.

Raharjo, T., Kawuryan, F., \& Ahyani, L. N. (2011). Identifikasi Learning Disability pada Anak Sekolah Dasar. Jurnal Sosial Budaya, 4(2), 136142. 
Rapin, I. (2016). Dyscalculia and the calculating brain. Pediatric neurology, $61,11-20$.

Santrock, J.W. (2007). Life-Span Development. NY: McGraw-Hill.

Shalev, R. S., Auerbach, J., Manor, O., \& Gross-Tsur, V. (2000). Developmental dyscalculia: prevalence and prognosis. European child $\mathcal{E}$ adolescent psychiatry, 9(2), S58-S64.

Shin, M., \& Bryant, D. P. (2015). A synthesis of mathematical and cognitive performances of students with mathematics learning disabilities. Journal of learning disabilities, 48(1), 96-112.

Triharso, A. (2013). Permainan kreatif dan edukatif untuk anak usia dini. Yogyakarta: CV Andi Offset.

Usman, H., \& Akbar, P. S. (2009). Metode penelitian sosial. Jakarta: Bumi Aksara.

Vitoria, L., \& Monawati, M. (2016). Improving Students' Problem Solving Skill in Mathematics Through Writing. Jurnal Ilmiah Peuradeun, 4(2), 231-238. doi:10.26811/peuradeun.v4i2.100

Walidin, W., Idris, S., \& Tabrani ZA. (2015). Metodologi Penelitian Kualitatif $\mathcal{E}$ Grounded Theory. Banda Aceh: FTK Ar-Raniry Press.

Williams, A. (2013). A teacher's perspective of dyscalculia: Who counts? An interdisciplinary overview. Australian Journal of Learning Difficulties, 18(1), 1-16. 